\section{Club for Research on Ageing}

IN 1939 a Club for Research on Ageing was established. This actually represents a team of medical and scientific research workers for study and researoh on ageing, and is not a society in the ordinary sense of the word. There are branches of the Club in Great Britain, the United States, France, the Argentine, and also members in Denmark and Switzerland. A branch in Sweden is in process of formation. The governing bodies of the branches are as follows-Great Britain: Prof. G. R. Cameron, Prof. E. C. Dodds, Sir Robert Robinson (chairman), Lady Robinson (hon. treasurer), Prof. M. J. Stewart, Dr. V. Korenchevsky (hon. secretary); United States: Prof. W. de B. MacNider (chairman), Dr. E. J. Stieglitz (secretary); with executive committee, Prof. E. V. Cowdry (chairman), Prof. A. B. Hastings and Prof. H. S. Simms; the Argentine : Prof. B. H. Houssay (chairman) and Dr. E. E. Krapf (hon. secretary); France: Prof. R. Courrier (hon. secretary).

There are only seventy-five members of the Club, which is limited to scientific and medical research workers who are engaged in, or direct, research on ageing or promise to do so, and who belong to qualified research laboratories or hospitals. Lord Nuffield and later the Nuffield Foundation generously supported a scheme of clinical research work carried out in co-operation with the London County Council at one of the Council's hospitals (Tooting Bec Hospital). The results of these clinical trials are now being examined. At the end of 1944, Lord Nuffield also gave a donation of $£ 3,000$ in order to establish an experimental laboratory for research on ageing, the Gerontological Research Unit, at present housed at the Departments of Zoology and Physiology of the University of Oxford; the head of the Unit is Dr. V. Korenchevsky. The American branch of the Club has had annual conferences, at which the schemes of research were discussed and planned, a museum of senile tissues was established, clinical research on the effects of vitamins on old persons was started at the Elgin Hospital, and finally a Journal of Gerontology was started. For the latter purpose a "Gerontological Society, Inc." was formed, consisting of the members of the American branch; the editor-in-chief is Dr. Robert A. Moore, professor of pathology of Washington University. The committee on publications consists of Profs. Roy G. Hoskins (chairman) and W. de B. MeNider, and Drs. P. Bronson, L. K. Frank and E. J. Stieglitz. The correspondent for Great Britain is Dr. V. Korenchevsky. The Journal, which will be published quarterly, will contain reviews and abstracts on gerontology as well as original papers. The address of the Journal is 507 South Euclid, St. Louis, U.S.A.

\section{Treatment of Lupus with Calciferol}

THE promising results of the treatment of lupus by means of large doses of calciferol are discussed in an annotation in the Lancet (23, Jan. 5, 1946). Dr. G. B. Dowling and Dr. E. W. Prosser Thomas have so far treated in this way thirty-eight subjects suffering from lupus, and sixteen of them have been followed up for more than a year. Dr. Dowling concludes that all of them have improved, and the lesions of twelve seem to have disappeared entirely. One subject has experienced no return of the disease during the eighteen months since the treatment was discontinued. Most of the subjects had made poor progress under the influence of other remedies. The treatment is cheaper and simpler than the ultraviolet rays and Finsen light often used, but the doses of calciferol necessary may cause such toxic effects as nqusea, loss of appetite and depression. Most of the eight subjects who showed these symptoms of the toxicity of the calciferol had been having 150,000 t.v. of it daily, and the symptoms of intolerance in all of them disappeared when the dose was reduced to 100,000 I.U. It is possible that some of these toxic effects may be due to products of the irradiation of ergosterol used to produce the calciferol. Very large doses of it may also cause abnormal calcifications in the renal tubules and arterioles and other soft tissues, and this fact must be taken into consideration (see also Proc. Roy. Soc. Med., 39, 96 ; 1945).

\section{University Grants}

Mr. Dalton, Chancellor of the Exchequer, has announced in a Parliamentary written answer that he proposes to ask Parliament to vote $£ 9,450,000$ for grants to the universities of Great Britain for 1,946-47. This is $£ 3,800,000$ more than was voted last year. It includes a further $£ 2,250,000$ for capital grants, a revote of $£ 1,200,000$ which has not been spent in 1945-46, and an additional $£ 100,000$ for dental education. In order to encourage universities to plan future development over a term of years, he has told the University Grants Committee that he will be prepared, if good cause is shown, to ask Parliament to vote even larger capital sums.

\section{University of London}

THE title of professor emeritus of aviation in the University of London has been conferred on Prof. Leonard Bairstow, Zaharoff professor of aviation at the Imperial College of Science and Technology from 1923 until his retirement in 1945 . The title of professor emeritus of education in the University has been conferred on Sir Fred Clarke, director of the Institute and professor of education at the Institute of Education from 1936 until his retirement in 1945. The title of professor emeritus of plant physiology in the University has been conferred on Prof. T. G. Hill, professor of plant physiology at University College from 1929 until his retirement in 1945.

Prof. Wilson Smith, since 1939 professor of bacteriology in the University of Sheffield, has been appointed to the University chair of bacteriology tenable at University College Hospital Medical School. Prof. V. Gordon Childe, since 1927 Abercromby professor of prehistoric archæology in the University of Edinburgh, has been appointed to the University chair of prehistoric European archæology and to the directorship of the Institute of Archæology.

Brigadier T. S. J. Anderson has been appointed external registrar of the University as from March 1 in succession to Mr. A. Clow Ford, who has been appointed director of extra-mural studies.

The degree of D.Se. has been conferred on Mr. N. F. Maclagan, of Middlesex Hospital Medical School.

\section{Rockefeller Travelling Fellowships in Medicine}

ThE Medical Research Council announces the resumption of the pre-war arrangement whereby it was enabled to award medical travelling fellowships generously provided by the Rockefeller Foundation of New York. For the current academic year, the Council has awarded fellowships to the following: 
Mr. G. S. Dawes, Department of Pharmacology, University of Oxford; Dr. J. L. Henderson, first assistant, Department of Child Life and Health, University of Edinburgh; Dr. R. S. Illingworth, late officer-in-charge of a medical division (Lieutenant-Colonel, R.A.M.C.); Mr. R. M. MayonWhite, Physiological Laboratory, Armoured Fighting Vehicles School, Lulworth; Dr. W. A. Law, late officer-in-charge of a surgical division (LieutenantColonel, R.A.M.C.) ; Mr. N. H. Martin, late assistant director of pathology, 21 Army Group and B.A.O.R. (Lieutenant-Colonel, R.A.M.C.) ; Dr. R. L. Richards, assistant physician, Neurovascular Unit, E.M.S. Hospital, Gogarburn, Edinburgh. Drs. Henderson and Illingworth were awarded fellowships in 1939, but were unable to take them up owing to the War.

\section{Comet Timmers (1946a)}

Positions of this comet have been recorded by several British observers, and an orbit has been computed by Dr. M. Davidson. Another orbit was computed by Cunningham from earlier observations, and the elements of both orbits are given below and also an ephemeris. It is approaching the sun and receding from the earth and is not likely to become a spectacular object. At the beginning of March its distances from the sun and earth are 1.8 and 1.07 astronomical units respectively.

$$
\begin{aligned}
& \text { Elements of the ORbit of Comet Timmers. } \\
& \text { Cunningham } \\
& \text { T } 1946 \text {, April 18.820 } \text { U.T. } 1946 \text {, April 14.341 U.T. }
\end{aligned}
$$

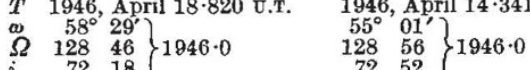

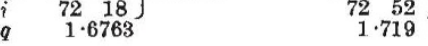

$$
\begin{aligned}
& \text { March } 1946 \\
& \begin{array}{c}
\text { Ephemeris } \\
\text { R.A. } \\
\begin{array}{c}
8 \mathrm{~h} 30 \cdot 3 \mathrm{~m} \\
7 \quad 54 \cdot 9
\end{array}
\end{array} \\
& \begin{array}{l}
\text { Dec. } \\
+67^{\circ} 37^{\prime} \\
71
\end{array}
\end{aligned}
$$

\section{T Coronæ Borealis}

This star is fading rapidly. On February 19 its magnitude was 8 . The earliest observation in Great Britain of the star was made by a boy of fifteen, M. Woodman, 61 Queen's Hill Crescent, Newport, Mon., who reported his observation to the Astronomer Royal. A note on the spectrum of the star, from the Solar Physics Observatory, Cambridge, appears on p. 270 of this issue.

\section{Announcements}

The Committee of Privy Council for the Organisation and Development of Agricultural Research has appointed Mr. Thomas Dalling, director of the Veterinary Laboratory of the Ministry of Agriculture and Fisheries, to be a member of the Agricultural Research Council, in succession to Mr. John Smith, whose term of office has expired.

Dr. N. E. ODELL, president of the Arctic Club and lecturer in geography in the University of Cambridge during 1932-40, is visiting Norway, Sweden and Denmark to lecture by invitation to learned societies, and also under the auspices of the British Council to general audiences, on British achievements in exploration.

THE following appointments have been made in the University of Birmingham: Dr. P. B. Moon, reader in atomic physics in the University, to be assistant professor of physics; Mr. C. H. M. Turner, to be lecturer in electrical engineering; Dr. J. W.
Abbis, to be lecturer in bacteriology; Dr. R. $H$. Bolton, to be full-time medical officer of the University.

The Medal for Merit, highest civilian decoration in the United States of America for war-time service, has been awarded by President Truman to Colonel Sosthenes Behn, president of the International Telephone and Telegraph Corporation, "for exceptionally meritorious conduct in the performance of outstanding services to the United Nations". As president of the International Telephone and Telegraph Corporation, Mr. Behn fostered extensive research and development on radio and telephone equipment; he also visited France and Belgium to re-organise communications laboratories, which enabled the latter to reproduce mobile radio equipment.

Av exhibition to provide an opportunity for trade and research organisations to inspect the facilities of The Metallurgy Division of the Royal Aircraft Establishment will be held in the laboratories at Farnborough during March 5-8 and March 11, from 9.30 a.m. to 4.30 p.m.

The Miners' Welfare Commission invites applications for a limited number of part-time day advanced mining scholarships tenable, as from September next, at approved institutions providing day classes in advanced mining instruction. Candidates for these scholarships must be wage-earning coal mine-workers, at least seventeen years of age on September 1, and have attended an approved part-time senior mining course. Application forms can be obtained from the principals of the mining schools.

Is accordance with its usual practice, Trinity College, Cambridge, announces the offer of a research studentship open to graduates of other universities who propose to go to Cambridge in October next as candidates for the degree of Ph.D. The value of the studentship may be as much as $£ 300$ a year. Candidates must not have reached the age of twenty-six before May 1. The College also offers, as usual, exhibitions of the value of $£ 40$ to students of Dominion and Colonial universities who wish to go to Cambridge next October as candidates for the degree of B.A., M.Litt., M.Sc. or Ph.D. A candidate for a studentship or exhibition should apply through the principal authority of his university, and his application should reach the Senior Tutor, Trinity College, Cambridge (from whom further particulars may be obtained) by May 1.

THE Ministry of Agriculture and Fisheries invites applications for: (1) ten senior scholarships, tenable at university departments of agriculture, agricultural colleges or veterinary colleges, for degree or diploma courses; (2) six extended junior scholarships (for those who have already held junior awards) ; and (3) sixty junior scholarships, tenable at farm institutes or similar institutions. The scholarships are open to the sons and daughters of agricultural workmen and to persons who are themselves bona fide workers in agriculture. The usual method of selection is by interview. Candidates for senior or junior scholarships must have attained the age of seventeen and sixteen years respectively by September 30, 1946. Forms of application (to be returned by April 30) may be obtained from the Secretary of the Ministry, Block 4, Bickenhall Mansions, Baker Street, London, W.1, or from the education offices of county councils. 